\title{
Dietary preference of the potamid crab Geothelphusa dehaani in a mountain stream in Fukuoka, northern Kyushu, Japan
}

\author{
SATOSHI KoBAYASHI \\ 3-36-36-401 Hakozaki, Higashi, Fukuoka 812-0053, Japan
}

Received 17 January 2012; Accepted 4 August 2012

\begin{abstract}
The diet of the potamid crab Geothelphusa dehaani was studied by examining the stomach contents of middle- and large-sized crabs (carapace width mostly $>10 \mathrm{~mm}$ ) in four seasons. Crabs were collected from a small mountain stream in Fukuoka City, Japan. Diet analysis was performed using the frequency of occurrence and percentage point methods. Geothelphusa dehaani was found to be omnivorous, with its feeding preference varying widely among individuals. However, the presence in the stomach of large amounts of tissues from various vascular plant organs was high for all seasons and size classes. The presence of moss and filamentous algae was relatively rare. The predominant animal tissue was from insects, $G$. dehaani preferring aquatic insects, especially caddisfly larvae (Trichoptera). Tissues of $G$. dehaani were also frequently found, suggesting the high prevalence of cannibalism of young crabs just after their release from maternal care. Spiders and sand were rarely found. Some fishes and snails were found, the former more common in large-sized male crabs. Feeding preferences and the postulated ecological niche were compared between the coexisting crabs G. dehaani and Eriocheir japonica: the former is an omnivore and a predator of small live animals, while the latter is an omnivore and scavenger that mainly eats detritus.
\end{abstract}

Key words: dietary preferences, ecological niche, freshwater crabs, Geothelphusa dehaani, potamid crab

\section{Introduction}

Potamids are brachyuran crabs well-adapted to the freshwater environment (true freshwater crabs): they have no planktonic larval stages in their life cycle and the female lays only a small number of large-sized eggs from which young crabs hatch directly. In Japan, there are 25 species, in the genera Geothelphusa, Candidiopotamon, Amamiku, and Ryukyum are distributed, most species reported only from the subtropical Ryukyu Islands (Suzuki \& Naruse 2012). Among these, Geothelphusa dehaani (White) has the widest (and unique) distribution, extending from Nakanoshima of the Tokara Islands northward to the Shimokita Peninsula, Aomori Prefecture (Koba 1936, Sakai 1976, Suzuki \& Tsuda 1991). This is the only potamid and true freshwater crab found in most temperate areas of Japan (Honshu, Shikoku and most of Kyushu), where it is common in the wetlands around mountain streams (low-order streams) at various altitudes up to 1500 m (Koba 1936, Suzuki 1992, Ishida 2010). Such a dis-

\footnotetext{
*Corresponding author: S. Kobayashi; E-mail, mokuzuz@rock.odn.ne.jp
}

tribution pattern suggests specific adaptation to the low temperatures and oligotrophic water quality of headwaters at high altitudes.

In freshwater, decapod crustaceans (such as detritivorus shrimps and grazing and omnivorous crayfishes) often play important roles in ecosystem cycling (Covich et al. 1999, Crowl et al. 2001). Introduced crayfish have a heavy impact on the freshwater ecosystems they have invaded (Hobbs et al. 1989, Gherardi 2007, Phillips et al. 2009). In Japan, distribution of the indigenous crayfish Cambaroides japonicus (de Haan) did not originally overlap with that of $G$. dehaani except in some parts of the Tohoku Region (Miyake 1982). This absence of crayfish originally may have allowed the uniquely wide distribution of $G$. dehaani within temperate Japan. Thus there is a possibility that $G$. dehaani competes with invasive alien crayfishes in lowtemperature areas (Usio et al. 2007). Understanding the ecological niche of this common large decapod crustacean in Japanese mountain stream communities is therefore important in approaching the conservation of freshwater biodiversity.

Geothelphusa dehaani can reach nearly $25 \mathrm{~mm}$ in cara- 
pace width $(\mathrm{CW})$ over four years (Araki \& Matsuura 1995a). It is one of the largest animals of stream benthos communities which are composed mostly of aquatic insects. Adult crabs, especially males, have large chelipeds, which they use for defense and to aid in feeding (Yamaguchi \& Takamatsu 1980), performing tasks which include breaking hard tissues (such as gastropod shells and the exoskeleton of coleopteran insects), the retreats of aquatic insects, and to capture fishes and large invertebrates. Furthermore, this crab is amphibious, found beneath underwater stones and stones immersed at the waterside, within debris at the waterside, and on the forest floor near streams (Shimotsukasa \& Wada 1995). It is difficult to confirm its exact population density over the total habitat range because this crab also digs burrows which are difficult to investigate, and not all crabs emerge at the waterside (Minei 1968). Although the density measured by quadrat sampling may be comparatively low among invertebrates, which generally show a patchy distribution within stream units, this species is spread over large areas because of its wide foraging in and around wetlands. Thus its potential food items vary considerably compared to other invertebrates in the river community, and its feeding habits connect the nutrient cycles of the terrestrial and aquatic environments.

Despite its importance, the feeding habits of this species and its exact ecological niche (position in the food web) are unclear. A few fragmented descriptions of its food habits are available (Shigenobu \& Kakuda 1978, Kanamori 1979), but no quantitative analysis has been reported. Stomach content analysis has been used to investigate the diet of brachyuran crabs, mainly those belonging to the Grapsoidae, Portunidae and Majidae (e.g. Bernardez et al. 2000, Cannicci et al. 1996, Chen et al. 2004, Vannini et al. 1989, Williams 1981) but there is little information available regarding the feeding preferences of the Potamidae, regardless of the large number of potamid species in tropical and subtropical freshwater environments (Yeo et al. 2008).

A previous study of stomach content analysis investigated the feeding preference of Eriocheir japonica (de Haan), the Japanese mitten crab (Kobayashi 2009). This catadromous varunid crab is widely distributed along the course of rivers in Japan, and often coexists with G. dehaani in the upper regions of rivers (mountain streams). In the temperate area of Japan many brachyuran species coexist in the brackish and sea area, but in freshwater rivers $G$. dehaani and E. japonica are the predominant brachyuran species (Kobayashi 2000).

The present study provides an analysis of the stomach contents of $G$. dehaani collected from a small mountain stream in Fukuoka City, northern Kyushu, contributing fundamental information about this crab and its feeding preferences in comparison with those of E. japonica, aiming to better understand the ecological niches of these two species in Japanese rivers.

\section{Materials and Methods}

The collection site was a wetland area including a stream channel and its banks (ca. $5 \mathrm{~m} \times 300 \mathrm{~m}$ ) located downstream of Nagatani Dam in a tributary of the Tatara River system in Fukuoka City, Japan $\left(33^{\circ} 39^{\prime} \mathrm{N}, 130^{\circ} 28^{\prime} \mathrm{E}\right)$. Most of this wetland is densely covered with riparian vegetation, including mosses, ferns, reeds, and trees which contribute abundant fallen leaves and dead branches to the stream substrate. Geothelphusa dehaani is abundant in all seasons at the collection site and was found resting in burrows dug under stones within the channel or on the banks, or found wandering in the water or over land. These crabs were collected with a hand net during a one-hour collection (23:00-24:00 h) in each of the four seasons: summer (July 30, 2006), autumn (October 18, 2006), winter (February 3,2007) and spring (May 2, 2007). At the collection site, large-sized ( $\mathrm{CW}>50 \mathrm{~mm}$ ) Eriocheir japonica were infrequently also collected from under large stones in the channel.

In the laboratory, crabs were fixed in $10 \%$ formalin within $1 \mathrm{~h}$ of collection. Sex was determined according to the shape of the pleopods and abdominal segments. Adults and juveniles (the exoskeleton and gonads are immature in the latter) were separated. Adult females are easily discriminated from juvenile females by the morphology of the abdomen (Araki \& Matsuura 1995b): small, almost triangular and with the edges of the thoracic sterna exposed in juveniles; abdomen nearly oval in outline and all parts of the thoracic sterna covered by the abdomen in adults. Male reproductive stages are not so easily discriminated morphologically as females. In the present study, therefore, morphological separation into adults and juveniles was applied tentatively only for females. Maximum CW was measured to the nearest $0.1 \mathrm{~mm}$ using digital calipers. Because of the difficulty of dissecting crabs of $\mathrm{CW}<6 \mathrm{~mm}$ (less than a year old; Araki \& Matsuura 1995a), only crabs of $\mathrm{CW} \geq 6 \mathrm{~mm}$ (mostly $\mathrm{CW}>10 \mathrm{~mm}$ ) were used for the analysis. For each specimen, the stomach was removed to examine the contents under a binocular microscope.

Quantitative analysis of the diet of $G$. dehaani was performed using frequency of occurrence and percentage point methods. Each method describes different aspects of the relative importance of food items, and the scores given by each are highly correlated for most food types. Feeding preferences of crabs can be directly quantified by the point method compared with the frequency of occurrence method. However, while the occurrence method is appropriate for most foods, the point method is generally unsuitable for foods containing a high proportion of soft tissue (Williams 1981).

The frequency of occurrence was calculated for each food item by dividing the number of individual crab stomachs containing the specific food item by the total number of crabs in the sample: 
frequency of occurrence $(\%)$ of the $i$ th food item $=100 \times \mathrm{A}_{i} / \mathrm{n}$

where $\mathrm{A}_{i}$ is the number of crabs whose stomachs contains the $i$ th food item, and $\mathrm{n}$ is the number of crabs analyzed in

Table 1. Calculation of the number of points for each food item: A, Key to relative contribution to stomach contents and score a; B, Key to degree of stomach fullness and score b. Point for each food item $=$ score $a \times$ score $b$. The maximum points possible for a single item in a single stomach is $100(100 \times 1.0)$; the minimum is $0.05(2.5 \times 0.02)$.

\begin{tabular}{cc}
\hline $\begin{array}{c}\text { A. Relative contribution of food } \\
\text { item to the stomach contents }\end{array}$ & Score a \\
\hline $95-100 \%$ & 100 \\
$65-95 \%$ & 75 \\
$35-65 \%$ & 50 \\
$5-35 \%$ & 25 \\
$<5 \%$ & 2.5 \\
Empty & 0 \\
\hline B. Degree of stomach fullness & Score b \\
\hline Full & 1.00 \\
$75 \%$ & 0.75 \\
$50 \%$ & 0.50 \\
$25 \%$ & 0.25 \\
Trace & 0.02 \\
\hline
\end{tabular}

July 30,2006

October 18
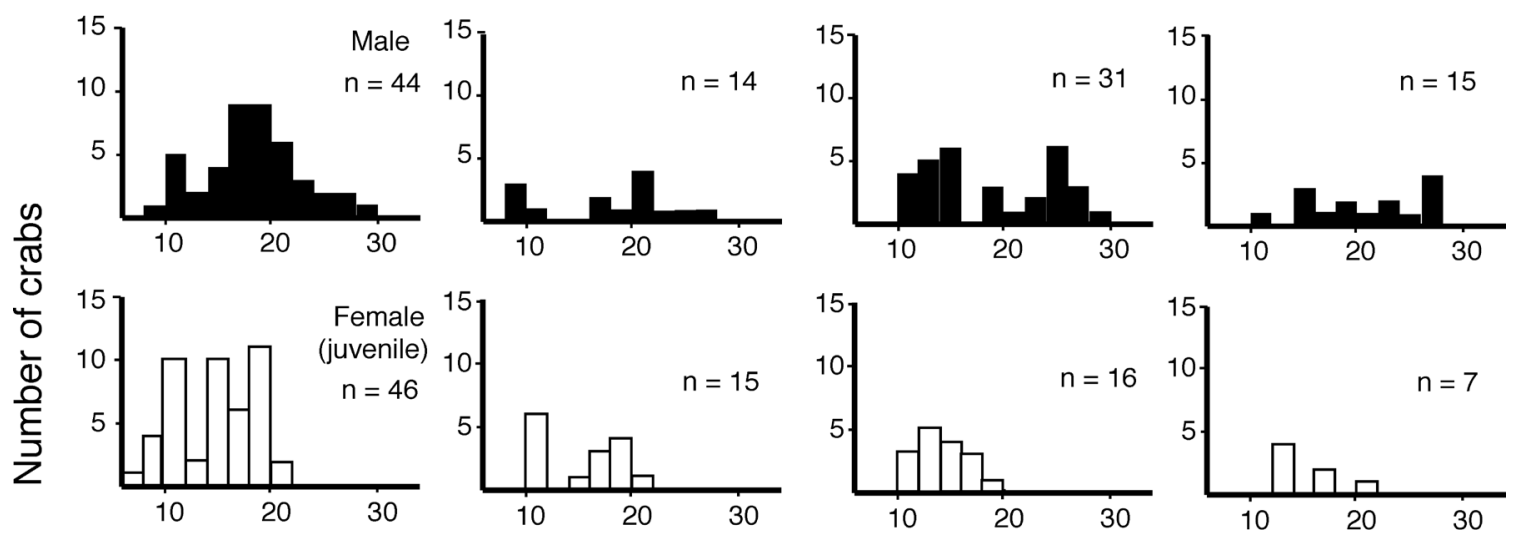

where $\mathrm{B}_{i j}$ is the number of points for food item $i$ in the stomach of the $j$ th crab, and $\mathrm{n}$ is the number of crabs analyzed, and $\mathrm{m}$ is the number of food items.

The number of points for each food item of each crab was calculated by multiplying the relative contribution to the stomach contents (score a) by a value dependent on the degree of stomach fullness (score b; Table 1). The cumulative number for each food item found in the stomach was then calculated using the frequency of occurrence, calculated as crabs were added, one at a time, to the analysis. Sand and unidentified materials were also considered as stomach content categories.

\section{Results}

\section{Carapace width (CW)}

The carapace widths of the collected crabs in all seasons

February 3, 2007

May 2
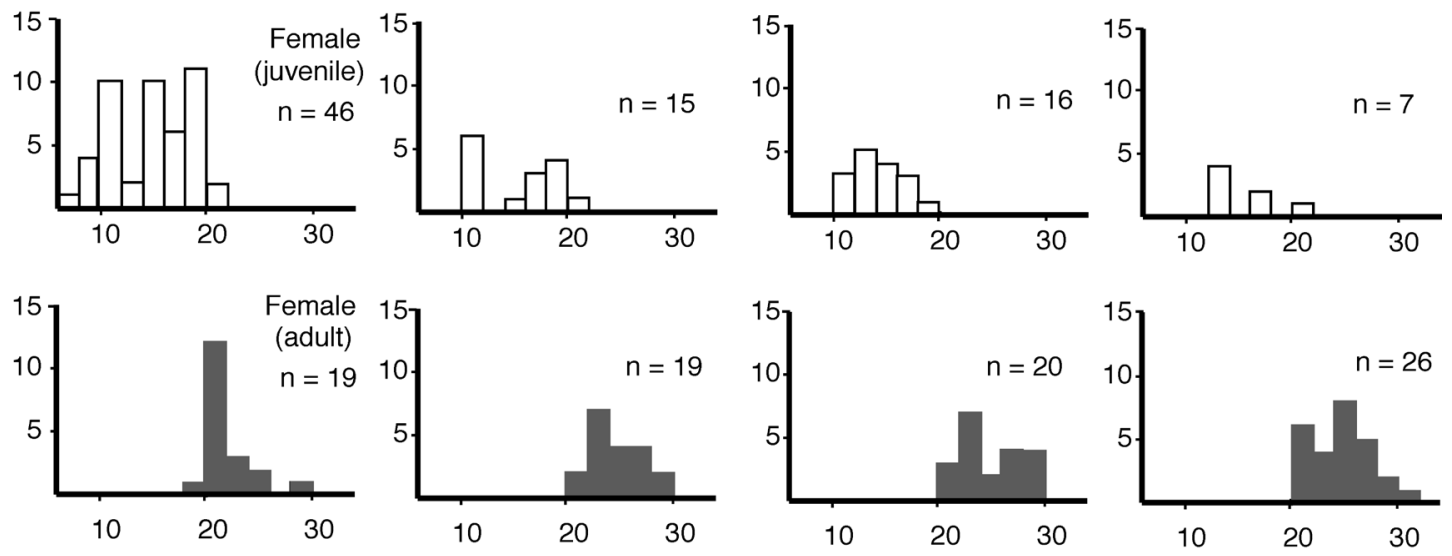

Carapace width $(\mathrm{mm})$

Fig. 1. Carapace width distribution of Geothelphusa dehaani samples collected in four seasons. 
ranged from 9.0 to $29.0 \mathrm{~mm}$ for males $(\mathrm{n}=104), 6.6$ to $20.8 \mathrm{~mm}$ for juvenile females ( $\mathrm{n}=84$ ), and 19.6 to $30.0 \mathrm{~mm}$ for adult females $(\mathrm{n}=84)$; that is, the size range was roughly the same for both sexes (Fig. 1). Among females, the ratio of adult to juvenile crabs reversed at $20 \mathrm{~mm} \mathrm{CW}$. Araki \& Matsuura (1995b) reported that puberty of $G$. dehaani occurs at $18-19 \mathrm{~mm} \mathrm{CW}$ in both sexes. Accordingly, in the present study males, too, were divided into small $(\mathrm{CW}<$ $20 \mathrm{~mm})$ and large $(\mathrm{CW} \geq 20 \mathrm{~mm})$ groups for food preference analysis in the present study.

\section{Stomach contents}

From a total of 277 specimens (103 males and 174 females) of $G$. dehaani collected, 68 males $(66.0 \%)$ and 100 females $(57.5 \%)$ had stomach contents that could be analyzed. Stomach contents were classified into four broad types, among which 10 kinds of food item were recognized (Table 2). Geothelphusa dehaani was found to be omnivorous with wide feeding preference.

I. Plant tissue: This included various vascular plants tissues, moss and algae growing around the sampling site. Vascular plants (item 1) included leaves, stems and roots of ferns, dicotyledonous and monocotyledonous spermatophytes. Both green (living) and brown (dead) materials were found. Freshwater filamentous algae (item 2) were Cladophora sp. Moss (item 3) was identified as Bryopsida.

II. Animal tissue: This included materials identified as tissues from animals living around the sampling site, mainly fragmented exoskeletons of arthropods including insects, spiders and crustaceans. Many items could be identified to at least the level of Order. Insects included various aquatic and terrestrial species (item 4). Spiders

Table 2. Stomach content categories for Geothelphusa dehaani collected from a mountain stream in Fukuoka.

\begin{tabular}{ll}
\hline \multicolumn{1}{c}{ Category/Item } & \multicolumn{1}{c}{ Details } \\
\hline $\begin{array}{l}\text { I. Plant tissue } \\
\text { 1. Vascular plant tissues }\end{array}$ & $\begin{array}{l}\text { leaves (fallen from broadleaf trees), stems, roots and lignified tissues } \\
\text { thallus (Bryopsida) } \\
\text { 2. Moss }\end{array}$ \\
$\begin{array}{ll}\text { 3. Algae } \\
\text { filamentous green algae }\end{array}$ \\
$\begin{array}{ll}\text { II. Animal tissue } & \text { fragmented exoskeleton, muscles and other tissues of aquatic and terrestrial insects } \\
\text { 5. Spiders } & \text { fragmented exoskeleton } \\
\text { 6. Crabs and other crustaceans } & \text { fragmented exoskeleton, muscles and other tissues of Geothelphusa dehaani and other crustaceans } \\
\text { 7. Fish } & \text { tissue with fins, scales and bones } \\
\text { 8. Snails } & \text { tissue with pieces of shell } \\
\text { III. Unidentified tissue } & \text { lumps of homogeneous tissue } \\
\text { IV. Sand } & \text { clastics ranging from } 62.5 \mu \mathrm{m} \text { to } 2 \mathrm{~mm}\end{array}$ \\
\end{tabular}

Table 3. Frequency of occurrence (\%) and percentage points in four food categories for both sexes of Geothelphusa dehaani. Numbers in parentheses indicate occurrence or points for each food category.

\begin{tabular}{|c|c|c|c|c|c|c|c|}
\hline & & & \multicolumn{4}{|c|}{ Food category } & \multirow{2}{*}{ Total } \\
\hline & & & Plant tissue & Animal tissue & Unidentified & Sediment & \\
\hline \multirow[t]{8}{*}{ Males } & \multirow[t]{4}{*}{ Small } & \multirow[t]{2}{*}{ Occurrence } & 78.4 & 29.7 & 10.8 & 0 & 100 \\
\hline & & & $(29)$ & $(11)$ & (4) & $(0)$ & (37) \\
\hline & & \multirow{2}{*}{ Point } & 72.5 & 21.7 & 5.9 & 0 & 100 \\
\hline & & & (1263.125) & $(378)$ & $(102)$ & $(0)$ & (1743.125) \\
\hline & \multirow[t]{4}{*}{ Large } & \multirow[t]{2}{*}{ Occurrence } & 83.3 & 46.7 & 3.3 & 10.0 & 100 \\
\hline & & & $(25)$ & $(14)$ & $(1)$ & (3) & $(30)$ \\
\hline & & \multirow[t]{2}{*}{ Point } & 66.8 & 30.3 & 2.8 & 0.2 & 100 \\
\hline & & & $(1362)$ & $(616.925)$ & $(56.25)$ & $(3.875)$ & (2039.05) \\
\hline \multirow[t]{8}{*}{ Females } & \multirow[t]{4}{*}{ Juveniles } & \multirow[t]{2}{*}{ Occurrence } & 75.6 & 55.6 & 6.7 & 4.4 & 100 \\
\hline & & & $(34)$ & $(25)$ & (3) & $(2)$ & $(45)$ \\
\hline & & \multirow[t]{2}{*}{ Point } & 71.4 & 21.0 & 7.5 & 0.1 & 100 \\
\hline & & & (1664.75) & $(490.1)$ & $(175)$ & $(2.55)$ & $(2332.4)$ \\
\hline & \multirow[t]{4}{*}{ Adults } & \multirow[t]{2}{*}{ Occurrence } & 78.9 & 45.6 & 15.8 & 8.8 & 100 \\
\hline & & & $(45)$ & $(26)$ & (9) & $(5)$ & $(57)$ \\
\hline & & \multirow[t]{2}{*}{ Point } & 70.1 & 22.4 & 7.2 & 0.4 & 100 \\
\hline & & & $(2390.5)$ & $(764.725)$ & $(244.5)$ & $(12.5)$ & $(3412.225)$ \\
\hline
\end{tabular}


were identified from pieces of setaceous exsoskeleton (item 5). Conspecific Geothelphusa dehaani was identified from pieces of carapace and legs. Other crustaceans were identified as gammarid amphipods or atyid shrimps (Caridina sp.) from the swimming legs and attached tissues (item 6). Fish tissues were identified from fins, scales and bones (item 7). They are probably the dark chub Nipponocypris temminckii (Temminck \& Schlegel), as this species is abundant in the streams investigated. Snails (item 8) were recognized from pieces of shell and elastic tissues. The pleurocerid lotic snail Semisulcospira libertina (Gould) is abundant in the underwater habitat of $G$. dehaani and is therefore a potential prey item. In addition, land snails (Bradybaenidae) grasped and broken by $G$. dehaani were observed at the collection sites.

III. Unidentified tissues were composed of lumps of homogeneous tissue, probably muscle of fishes or snails, or (if plant tissue) the endosperm of seeds or flesh of fruits.

IV. Sand: Clastics of nearly $62.5 \mu \mathrm{m}$ to $2 \mathrm{~mm}$ may be derived from sediment attached to food items, or pieces of

\section{Male}
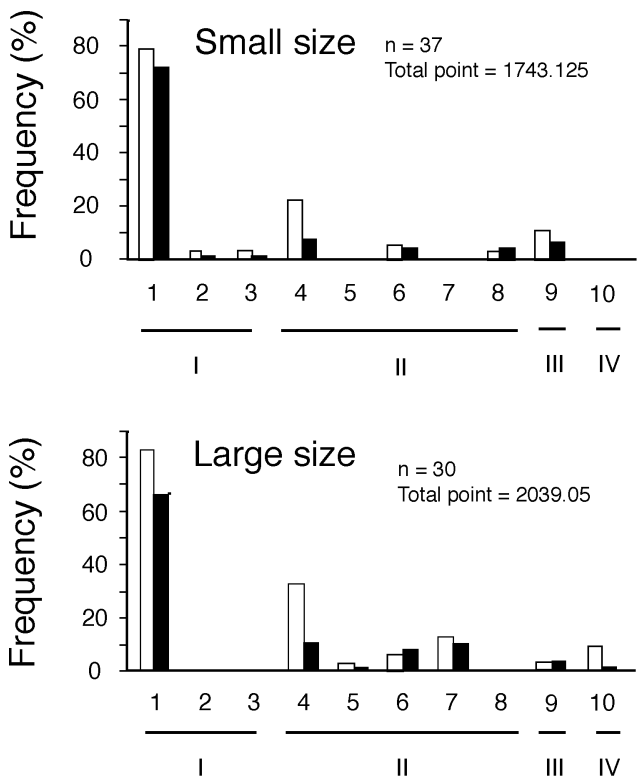

Food item
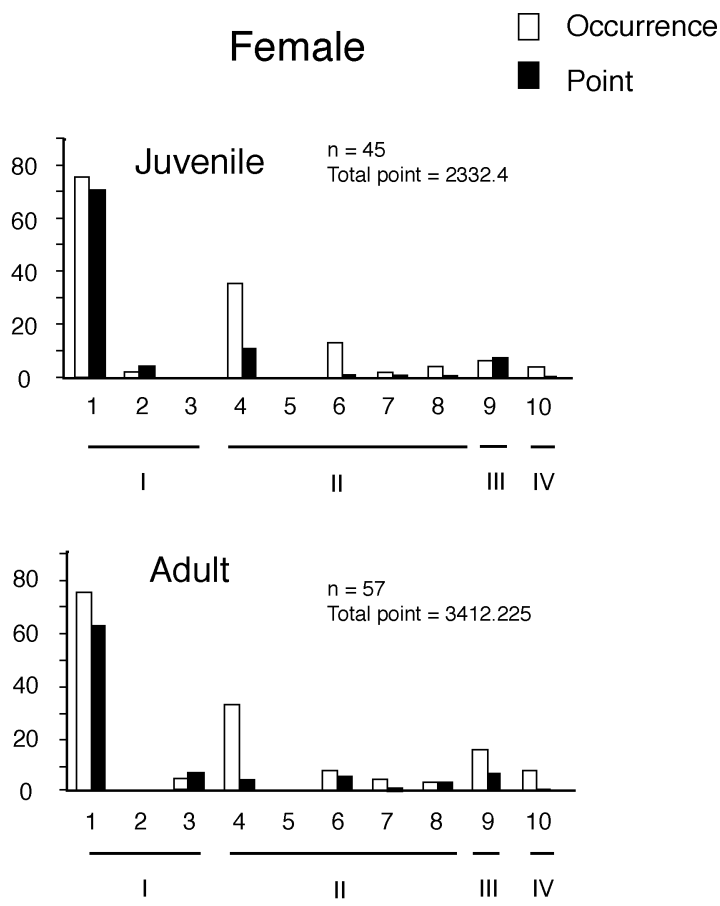

Food item

Fig. 2. Frequency of occurrence of the ten food item categories in the stomach contents of Geothelphusa dehaani for each sex and stage (frequency of occurrence and percentage point method). See Table 2 for the key to food item categories.

Table 4. Occurrence and point for arthropods collected from the stomach contents of Geothelphusa dehaani.

\begin{tabular}{|c|c|c|c|c|c|c|c|}
\hline Class & Order & Family & Genus/species & Larva/adult & $\begin{array}{l}\text { Aquatic/ } \\
\text { terrestrial }\end{array}$ & Occurrence & Point \\
\hline \multirow[t]{10}{*}{ Insecta } & Trichoptera & Hydropsychidae & & Larva & Aquatic & 12 & 332 \\
\hline & Plecoptera & & & Larva & Aquatic & 1 & 2 \\
\hline & \multirow[t]{3}{*}{ Ephemeroptera } & Heptageniidae & Epeorus sp. & Larva & Aquatic & 1 & 2 \\
\hline & & Isonychiidae & Isonychia japonica & Larva & Aquatic & 1 & 25 \\
\hline & & Baetidae & Baetis sp. & Larva & Aquatic & 3 & 7 \\
\hline & Diptera & Simuliidae & & Larva & Aquatic & 1 & 2 \\
\hline & Coleoptera & Psephenidae & Mataeopsephus sp. & Larva & Aquatic & 1 & 2.5 \\
\hline & Unidentified & & & Larva & Unidentified & 6 & 24.375 \\
\hline & Coleoptera & Carabidae & & Adult & Terrestrial & 4 & 82.75 \\
\hline & Unidentified & & & Unidentified & Unidentified & 20 & 216.7 \\
\hline Arachnida & Araneae & Pisauridae & Dolomedes raptor & Unidentified & Terrestrial & 1 & 37.5 \\
\hline \multirow[t]{2}{*}{ Crustacea } & Brachyura & Potamonidae & Geothelphusa dehaani & Unidentified & Amphibious & 14 & 362 \\
\hline & Other & & & & Aquatic & 1 & 100 \\
\hline
\end{tabular}


the retreats of aquatic insects.

\section{Food preference in 4 categories}

Data obtained for the four large categories for each sex and stage are shown in Table 3. Both sexes predominantly ate plants (75.6-83.3\% occurrence and $66.8-72.5 \%$ points) compared to animal materials (29.7-55.6\% and $21.7-$ $30.3 \%$, respectively). There were no evident differences in food preference among different sexes and stages. Food preference was statistically compared using the frequencies of occurrence in the three major food categories (sediment was omitted because of its low values) among the four groups of individuals (small- and large- sized males, and juvenile and adult females). No significant difference was observed for either the frequency of occurrence $\left(\chi^{2}\right.$ test, $\left.\mathrm{df}=6, \chi^{2}=6.134, p=0.4083\right)$ and percentage points $\left(\chi^{2}\right.$ test, $\left.\mathrm{df}=6, \chi^{2}=4.738, p=0.5778\right)$.

\section{Food item preferences}

Figure 2 shows the overall frequency distribution of the 10 types of food item. Vascular plant tissues (item 1) dominated in all groups as assessed by both frequency of occurrence (75.4-83.3\%) and percentage point (62.7-72.4\%) methods. Moss (item 2) and filamentous algae (item 3) were rare compared to tissues from vascular plant.

Insects (item 4) were predominant among animal tissues identified (21.6-36.7\% occurrence; $5.4-11.2 \%$ points). Crustaceans were also found frequently (5.4-13.3\% occurrence; $1.3-7.4 \%$ points). Spiders (item 5$)$ were very rare $(3.3 \%$ occurrence; $1.8 \%$ points), and were seen only in stomach contents from large males. Specific arthropod taxa could be identified (Table 4), including various aquatic insects (at least 5 orders and 7 species). Hydropsychid Trichoptera (caddisfly) larvae scored highly in both occurrence (12) and points (332), suggesting that $G$. dehaani preferred to eat attaching form larvae. Another attaching form insect, simuliid Diptera (blackfly) larvae was also identified. However, $G$. dehaani also ate a number of swimming, creeping and gliding insects including mayfly larvae (Ephemeroptera) such as Epeorus, Isonychia, and Baetis; stonefly larvae (Plecoptera); and psephenid water penny beetle (Coleoptera), in the genus Mataeopsephus. Terrestrial insects, too, had a relatively high points (82.75) and were identified mostly as carabid ground beetle adults (Coleoptera). Tissues from conspecific individuals ( $G$. dehaani) were also found frequently (14 in occurrence; 362 in points).

Fish (item 7) scored highly in large-sized males $(13.3 \%$ occurrence and $10.1 \%$ points) than in other groups $(0-5.3 \%$ occurrence; $0-2.0 \%$ points).

Sand (item 10) scored very low in points $(0-0.4 \%)$ compared to occurrence (0-10.0\%).

Seasonal variation in stomach contents for 10 food items is shown in Fig. 3. Vascular plant tissues (item 1) were similarly predominant in all seasons, as assessed by both frequency of occurrence (69.4-87.5\%) and points (64.1$78.2 \%$ ). Occurrence of insects (item 4) was higher in
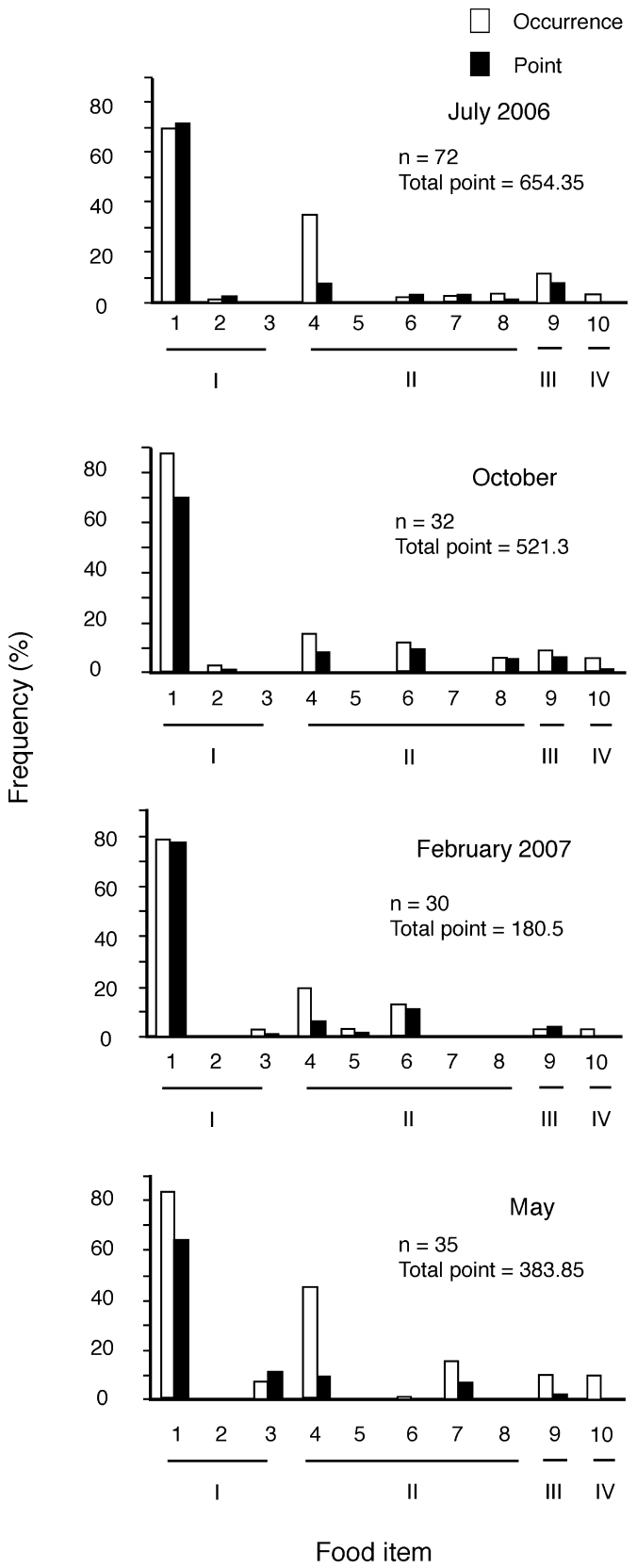

Fig. 3. Effect of seasonal changes on the frequency of occurrence of the ten food item categories in the stomach contents of Geothelphusa dehaani (frequency of occurrence and percentage point method). See Table 2 for the key to food item categories.

spring and summer (45.7 and 36.1\%) compared to autumn and winter (15.6 and 23.3\%). In autumn and winter, crustaceans (No. 6) increased in terms of both frequency of occurrence (12.5 and 13.3\%) and points (9.0 and 10.6\%).

\section{Discussion}

\section{Feeding preference of $G$. dehaani}

The results of the present study indicating that $G$. dehaani 
is a herbivory-biased omnivore is in accordance with previous assessments (Shigenobu \& Kakuda 1978, Kanamori 1979). Shimotsukasa \& Wada (1995) reported that middleand large-sized $G$. dehaani appeared at similar frequencies in terrestrial and underwater habitats (nearly 50\% each), suggesting that crabs had similar opportunities for encountering food items in both habitats. Dense vegetation along the river channel at the collection site provided abundant vascular plant tissues. However, low illuminance and oligotrophic water led to low coverage of algae on the rocks under the water. Such an environment may explain the preference of $G$. dehaani for vascular plant tissues.

In addition, G. dehaani is a predator in both in the underwater and terrestrial environments. Among aquatic insects, trichopteran larvae were frequently eaten compared to insects of other orders. This preference may be because of the ease of capturing them. Hydropsychid trichoptera (caddisfly) larvae are nest-builders, but $G$. dehaani with its large chelipeds can easily break their retreats and capture these sessile larvae. In addition, these net-spinning caddisfly larvae are often predominant at sites downstream of dams as with the present study sites (Matsui 2008, Takemon 2009). Although there is no data on the density of each stream benthos species in the present survey, their abundance may affect the frequency of predation. However, several swimming or gliding ephemeropteran (mayfly) larvae were also eaten by $G$. dehaani. These larvae move actively on the surface of rocks in the area of rapids. Thus $G$. dehaani actively captures rapidly-moving preys in their foraging. Fishes, probably Nipponocypris temminckii (Temminck \& Schlegel), were eaten by large G. dehaani with large chelipeds. They may be able to easily catch juveniles of such swimming fishes. Snails in the stomach contents could be the lotic snail Semisulcospira libertina or land snails (Bradybaenidae). Predation on S. libertina has been estimated from a study of infection of $G$. dehaani by parasites (Shibahara 1991). These slow-moving animals are easy to capture and their shells can be broken by chelipeds.

Tissues of G. dehaani were found frequently. Their frequency of molting is limited (2-3 times per year, Yamaguchi \& Takamatsu 1980) and their exuviae are not frequently found in their habitat suggesting the possibility of cannibalism. Cannibalism of live young crabs by adult crabs has been observed in a laboratory experiment (Oshima et al. 1994). The occurrence of crabs in stomach contents increased in autumn and winter, times that corresponds with the season when young crabs (less than a year old) are abundant in their habitat following their release from maternal care typically in August or September (Yamaguchi \& Takamatsu 1980, Araki \& Matsuura 1995a).

The low scores for sediment components (sand) suggest that foods were sorted by the chelipeds to some extent and that crabs do not directly bring detritus to their mouth. In addition, animals are captured when they were alive in most cases.
It is clear that $G$. dehaani is a fierce predator on small wetland animals, showing a wide variety of prey in the present survey, although the occurrence in each crab stomach contents was relatively low for a particular species. From this it is concluded that this crab is an opportunistic predator and a potential predator of any other small animals in its habitat.

\section{Difference of ecological niche between $G$. dehaani and Eriocheir japonica}

Substantial differences have been shown in the feeding preferences of the Japanese mitten crab Eriocheir japonica previously investigated using the same methods (Kobayashi 2009). Eriocheir japonica inhabits only underwater environments under normal conditions. This crab is a herbivory-biased omnivore and a detritus feeder (scavenger) that does not sort its food well and often swallows sediment components (mud and sand) along with large detritus. The frequency of predation on live animals is very low, especially during the juvenile stage (river phase). Thus E. japonica is a detritus food web member functioning as a shredder that decomposes large detritus (CPOM, coarse particle organic matter) into small particles (FPOM, fine particle organic matter) (Kobayashi 2009). In the upper regions of rivers (mountain streams), large crabs with large chelipeds $(\mathrm{CW}>50 \mathrm{~mm})$ are distributed in the deeper underwater areas of the main stream (Kobayashi \& Matsuura 1991), and predation on this species by other animals is considered to be low.

In contrast, $G$. dehaani is amphibious. This species is not only a herbivory-biased omnivore but also a predator of various small animals living in the wetlands. It is also potential prey for various larger animals in both aquatic and terrestrial habitats (e.g., fishes, toads, birds and mammals). Infection with lung flukes (diploid Paragonimus westermani (Kerbert) and P. miyazakii Kamo, Nishida, Hatsushika \& Tomiura) from $G$. dehaani to mammals is well documented in Japan (Shibahara \& Nishida 1985). The abundance of such parasites and continued existence of infection routes demonstrate the continuous predator-prey relationships between $G$. dehaani and mammals. Thus $G$. dehaani may occupy a niche in the complex food webs within the wetland ecosystems connecting underwater and terrestrial environments along mountain streams.

\section{References}

Araki A, Matsuura S (1995a) Growth of a freshwater crab, Geothelphusa dehaani (White). Sci Bull Fac Agr Kyushu Univ 49: 125-132. (in Japanese)

Araki A, Matsuura S (1995b) Relative growth and gonadal maturation of a freshwater crab Geothelphusa dehaani. Nippon Suisan Gakkaishi 61: 510-517.

Bernardez C, Freire J, Gonzalez-Gurriarian E (2000) Feeding of the spider crab Maja squinado in a rocky subtidal areas of the Ria de Arousa (north-west Spain). J Mar Biol Ass UK 80: 95- 
102.

Cannicci S, Dahdouh-Guebas F, Anyona D, Vannini M (1996) Natural diet and feeding habits of Thalamita crenata (Decapoda: Portunidae) J Crust Biol 16: 678-683.

Chen RB, Watanabe S, Yokota M (2004) Feeding habits of an exotic species, the Mediterranean green crab Carcinus aestuarii, in Tokyo Bay. Fish Sci 70: 430-435.

Covich AP, Palmer MA, Crowl TA (1999) The role of benthic invertebrate species in freshwater ecosystems. BioSci 49: 120 127.

Crowl TA, McDowell WH, Covich AP, Johnson SL (2001) Freshwater shrimp effects on detrital processing and nutrients in a tropical headwater stream. Ecol 82: 775-783.

Gherardi F (2007) Understanding the impact of invasive crayfish. In: Biological Invaders in Inland Waters: Profiles, Distribution, and Threats (ed Gherardi F). Springer, Berlin, pp. 507542.

Hobbs HH III, Jass JP, Huner JV (1989) A review of global crayfish introductions with particular emphasis on two North American species (Decapoda, Cambaridae). Crustaceana 56: 299-316.

Ishida S (2010) Aquatic invertebrates and freshwater environment-from water quality to landscape- - In: Indicator Biology in the Riverain Environment. (ed Tanida K). Hokuryukan, Tokyo, pp. 95-102. (in Japanese)

Kanamori M (1979) Daily activity of Geothelphusa dehaani. Collecting and Breeding 41: 593. (in Japanese)

Koba K (1936) Some observation on Geothelphusa dehaani (White) in Japan. Botany and Zoology 4: 529-536. (in Japanese)

Kobayashi S (2000) Distribution pattern and ecology of brachyuran crabs in the riverine environment: their significance in the ecosystem and present condition. Ecol Civil Eng 3: 113130. (in Japanese)

Kobayashi S (2009) Dietary preferences of the Japanese mitten crab Eriocheir japonica in a river and adjacent seacoast in north Kyushu, Japan. Plankton Benthos Res 4: 77-87.

Kobayashi S, Matsuura S (1991) Longitudinal distribution of the Japanese mitten crab in the Kaminokawa River, Kagoshima. Nippon Suisan Gakkaishi 57: 1029-1034. (in Japanese)

Matsui A (2008) Effects of Oishi Dam (Sekikawa Village, Niigata Prefecture, Japan) on downstream macroinvertebrate assemblages with particular focus on net-spinning caddisflies. Ecol Civil Eng 11: 175-182. (in Japanese)

Minei H (1968) Japanese potamids. Nature Study 14: 94-99. (in Japanese)

Miyake S (1982) Japanese Crustacean Decapods and Stomatopods in Color Vol.1. Hoikusha, Osaka. pp. 261. (in Japanese)

Oshima K, Wada K, Fukui Y (1994) A laboratory study on interactions between individuals of the freshwater crab Geothelphusa dehaani. Biol Inland Wat 9: 9-17. (in Japanese)
Phillips ID, Vinebrooke RD, Turmer MA (2009) Ecosystem consequences of potential range expansions of Orconectes virilis and Orconectes rusticus crayfish in Canada-a review. Env Rev 17: 235-248.

Sakai T (1976) Crabs of Japan and the adjacent Seas. Kodansha, Tokyo. 773 pp. with 251 pls.

Shibahara T (1991) The route of infection of Paragonimus westermani (diploid type) cercariae in the freshwater crab, Geothelphusa dehaani. J Helminthol 65: 38-42.

Shibahara T, Nishida H (1985) An epidemiological survey of the lung fluke, Paragonimus spp. in wild mammals of the northern part of Hyogo Prefecture, Japan. Jpn J Veterinary Sci. 47: 911919.

Shigenobu Y, Kakuda S (1978) Ecology, physiology and embryology of Geothelphusa dehaani and development of teaching materials. Collecting and Breeding 40: 440-443. (in Japanese)

Shimotsukasa H, Wada K (1995) Distribution of the freshwater crab Geothelphusa dehaani in relation with season, sex and body size. Biol Inland Waters 10: 18-25. (in Japanese)

Suzuki H, Tsuda E (1991) Study on the color variation and distribution of a freshwater crab, Geothelphusa dehaani (White) in Kagoshima Prefecture. Benthos Res 41: 37-46.

Suzuki H, Naruse T (2012) Freshwater Decapoda Crustaceans in Japan. In: Shrimps, Crabs and Crawfish-Conservation and Biology of Freshwater Crustaceans-. (eds Kawai T, Nakata K). Seibutsukenkyusha, Tokyo, pp. 39-73. (in Japanese)

Suzuki T (1992) Coloration and distribution of the Japanese freshwater crab, Geothelphusa dehaani (White), in the Hanamizu River on Tanzawa Mountains, Kanagawa Prefecture. Natural History Report of Kanagawa 13: 55-64. (in Japanese)

Takemon Y (2009) Changes of sediment environment and benthos assemblages in the rivers below dams. In: Science of Dam and Environment-I. Ecosystem below Dams. (ed Ikebuchi S). Kyoto University Press, Kyoto, pp. 147-176. (in Japanese)

Usio N, Nakata K, Kawai T, Kitano S (2007) Distribution and control status of the invasive signal crayfish (Pacifastacus leniusculus) in Japan. Jpn J Limnol 68: 471-482. (in Japanese)

Vannnini M, Chelazzi G, Gherardi F (1989) Feeding habits of the pebble crab Eriphia smithi (Crustacea, Brachyura, Menippidae). Mar Biol 100: 249-252.

Wiliams MJ (1981) Methods for analysis of natural diet in portunid crabs (Crustacea: Decapoda: Portunidae). J Exp Mar Biol Ecol 52: 103-113.

Yamaguchi T, Takamatsu Y (1980) Ecological and morphological studies on Japanese freshwater crab, Geothelphusa dehaani. Kumamoto J Sci Biol 15: 1-27.

Yeo DC, Ng PKL, Cumberlidge N, Magalhaes C, Daniels SR, Campos MR (2008) Global diversity of crabs (Crustacea: Decapoda: Brachyura) in freshwater. Hydrobiologia 595: 275286. 